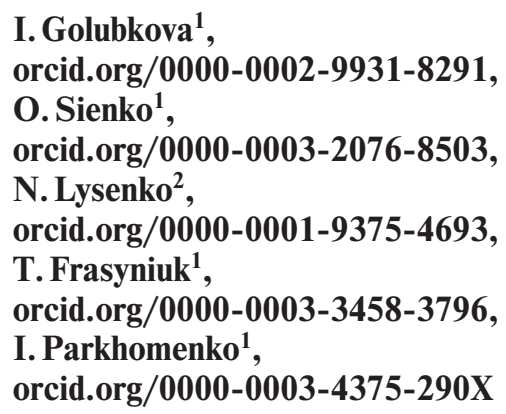

1 - National University “Odesa Maritime Academy”, Odesa, Ukraine, e-mail: prof.irinagolubkova@gmail.com 2 - PC "Vavilont", Odesa, Ukraine

\title{
CRITERIA FOR THE MANAGEMENT OF A SUSTAINABLE AND SAFE POSITIONING OF THE FLEET IN THE CONDITIONS OF GLOBALIZATION
}

Purpose. To develop a model of minimizing transportation risks for strengthening the criteria for sustainable and safe positioning of the fleet.

Methodology. Scientific research, whose results are given in the presented article, is performed using both general and special methods of cognition. Methods of quantitative and qualitative comparison, content analysis, scientific abstraction and systematization and the method of mathematical formalization were used.

Findings. An algorithm of a criterion-based approach to sustainable and safe positioning of the fleet in the presence of international transport market constraints is proposed. A mathematical model has been developed for minimizing transportation risks, which will reduce the current costs of the merchant fleet and, accordingly, contribute to its sustainable and safe positioning. Since it is important for industrial enterprises to reduce the time and cost of delivering raw materials, components, reducing transport costs for delivering products to the consumer, the paper presents forecasting of volumes of container transportations through ports of Ukraine and comparative analysis with the forecast trend of container transportations in the world market. This made it possible to form a tool for determining the appropriate positioning of the fleet.

Originality. The study developed an algorithm for a criteria-based approach to sustainable and safe fleet positioning under international transport market constraints and a mathematical model to minimize transportation risks. This allows moving over to the formation of an integrated multimodal transport system and coordinated actions of all market participants in transport services. The efficiency and reliability of the system will be enhanced by the ability to predict the reorientation of routes associated with increased risk and dynamic management of traffic flows.

Practical value. The results of the study can be used to create integrated automated information systems for dynamic traffic management using alternative routing of traffic flows to minimize risks. The results of the forecast study on container traffic through Ukrainian seaports can be used for practical or scientific purposes.

Keywords: innovative technologies, maritime transport, criteria of sustainable operation, efficiency, positioning, management

Introduction. Ukraine has signed a number of agreements that open wide opportunities for the development of its own fleet. In particular, the agreement on the Free Trade Area with the EU provides an opportunity for Ukrainian transport companies to enter the market of maritime and inland waterway transport in European countries. As the EU seeks to increase water transport by reducing the share of land transport accordingly, this opens up additional significant prospects for Ukraine. Ukraine's prospects are strengthened by the fact that so far it has significant advantages in the European market in comparison with all post-Soviet countries. For a stable and safe positioning of the Ukrainian fleet in this and other markets, maritime transport companies must meet all the necessary criteria. First of all, the key to this is the effective and advanced introduction of new innovative technologies that will ensure the competitiveness of the Ukrainian fleet and ports of Ukraine in the global market of sea and river transport.

Literature review. The problem of effective management of sustainable and safe positioning of the fleet is a global one, so both Ukrainian and foreign scientists have devoted their scientific works to its research. Yavorska [1], in particular, studied the patterns and differences in the management of shipping companies under the influence of changes in the economic situation and regulatory activities of relevant international organizations. Yavorska [1] points out that fierce competition for innovative resources leads to asymmetry in the technical and economic level of fleets of different countries and this affects the nature of

(C) Golubkova I., Sienko O., Lysenko N., Frasyniuk T., Parkhomenko I., 2021 reactions of shipowners and logistics operators to global market challenges. In the work by Golubkova [2] the parameters of the functional activity of the merchant fleet, in particular, specialization in cargo flows; parametric structuring; dynamism with uneven depreciation of the capital of the cruise complex, its intensity and efficiency; balance of internal structure; systemic changes in fleet productivity, and others are singled out. Sienko [3] points out that the increase in carrying capacity while strengthening the requirements for maritime safety limits the possibility of positioning maritime countries with economies in transition in capital-intensive segments of the maritime transport market. Makarenko, et al. [4] points to the peculiarity of the Ukrainian fleet, where the growing number of high-performance ships of new generations is combined with the presence of ships that increase the risk of balancing the quality and price of transportation. Nitsenko, et al. [5] and Koliadenko, et al. [6] point out the importance of strengthening the requirements for management in the implementation of external administration to ensure the sustainable functioning of the fleet, which affects the choice of strategy and objectives for positioning Ukraine in the market of transport services. The article by Sotnichenko, et al. [7] points out the importance of managing the innovation potential of the sea trade port for its positioning. Kosharskaya, et al. [8] applied a systematic approach to the development of the design of the shipping safety management system, which is also a factor in ensuring the positioning of the fleet. Bubnova, et al. [9] also points to the importance of innovation for the positioning of the merchant fleet. In [10] a project is presented for the development of the maritime industry, which will contribute to the formation of effective management of sustainable and 
safe positioning of the fleet. Kolehaiev [11] presented a new approach to the formation of the principles of competitive development of specialized shipping. In $[10,12]$ the need to minimize the risks of transportation as one of the criteria for the positioning of the fleet is mentioned.

Unsolved aspects of the problem. These scientific works are a solid basis for solving the problematic aspects of the formation of sustainable and safe positioning of the fleet. Unfortunately, the issues of reducing the risks of maritime transport by enhancing the effectiveness of real-time management of transport enterprises, in particular, to reduce the risks of logistics systems are left out from the attention of the scientific community. This is impossible without the introduction of innovative technologies, the latest algorithms and mathematical models. Therefore, the question of creating a mathematical model to improve the management of transport companies and, consequently, increase the level of sustainable and safe positioning of the fleet remains open. In modern conditions, the dynamic nature of the changing effects of risks on the transportation of goods necessitates advanced management in real time for the stable positioning of shipping companies. Therefore, the main purpose of the article is to form a mathematical model to reduce transportation risks.

Purpose of the article: develop a model to minimize transportation risks to strengthen the criteria for sustainable and safe positioning of the fleet.

Methods. The scientific research, whose results are given in the presented article, was performed using both general and special methods of cognition. The application of a block of methods of quantitative and qualitative comparison allowed analyzing the effects on the volume of transit cargo through the ports of Ukraine. The use of content analysis allowed, in particular, establishing the impact of risks on the volume of transit cargo in certain areas.

The main methods used during the research were the methods of scientific abstraction and systematization and the method of mathematical formalization.

Methods of scientific abstraction and systematization were used in the development of a general algorithm for a criterial approach to sustainable and safe positioning of the fleet in the presence of restrictions on the international transport market. The method of mathematical formalization was used in the development of a mathematical approach to minimizing the risks of transportation of goods, which, as indicated by the use of auxiliary methods, in particular, content analysis and logical generalization, allows reducing losses and forming appropriate technology - economic level of maritime transport, which ensures the efficiency of service of cargo flows.

Results. Results of application of methods, content analysis, scientific abstraction and systematization. Cargo flows of maritime transport enterprises are formed in accordance with the peculiarities of the economic systems of the regions and the advantages of these enterprises in proximity to international transport corridors. In these circumstances, tariffs and relative prices for transport services are crucial. Economic equilibrium, which is the key to sustainable and safe positioning of the fleet, is achieved with the appropriate ratio of prices of transport services and the cost of transporting goods.

The importance of transportation management criteria increases with increasing variability of investment processes and efficient operation of maritime transport enterprises. The requirement for the criteria is also the fact that, in order to form a sustainable and safe positioning of the fleet, they must contribute to the balanced growth of cargo flows and the efficient use of capacity of both maritime transport companies and the fleet as a whole. Therefore, the application of criteria that set limits to the parameters of the development strategy in the event of external change should form the basis of managing the sustainability of enterprise positioning.

The globalization of the economy leads to the fact that mutually beneficial cooperation between individual countries and individual ports is intensifying. On the other hand, it reduces the possibility of effective management of economic problems exclusively within an individual transport company or even a country. Therefore, the criterial approach should take into account not only the need to ensure the effective functioning of international transport corridors, serving the needs of the global economy but also take into account the needs and objectives of the regional economy. That is why, based on the criteria of economy, reliability and speed of delivery, the specific value of multimodal cargo transportation in the total volume of transportation increases. And the share of multimodal transportation in the total volume of cargo is a certain sign of the competitiveness of the fleet. And its increase or decrease is a corresponding sign of the positioning of the fleet, or even a single port, in the global market.

The optimal functional and financial stability of the maritime industry depends on two main groups of factors: external conditions, which correlate with competitive taxation and tariffs, and the effectiveness of business activities. Balancing on these main factors determines the choice of mechanism and set of positioning tools in the market of transport services on the basis of competitiveness. Management staff of transport companies in these circumstances should formulate development goals (Fig. 1). Under these circumstances, it is necessary to choose between increasing profitability and optimizing the value of the enterprise, i.e. its capitalization.

The focus on capitalization requires the implementation of policies to increase the technical and economic level of the maritime industry, which, in turn, requires investment, innovative technologies and empowerment of management staff to make project decisions that meet the main trends of the global maritime transport system.

Effective management of cargo growth is a guarantee of competitiveness of the maritime industry both in terms of dynamics and structure of freight flows, and, given this, the management of maritime transport companies must take into account changes in the innovative support of the international transport market. The competitive development of the world market of transport fleet services requires constant improvement of all aspects of the fleet, in particular, the effective implementation of innovations in all areas of external challenges of the national fleet for its sustainable positioning.

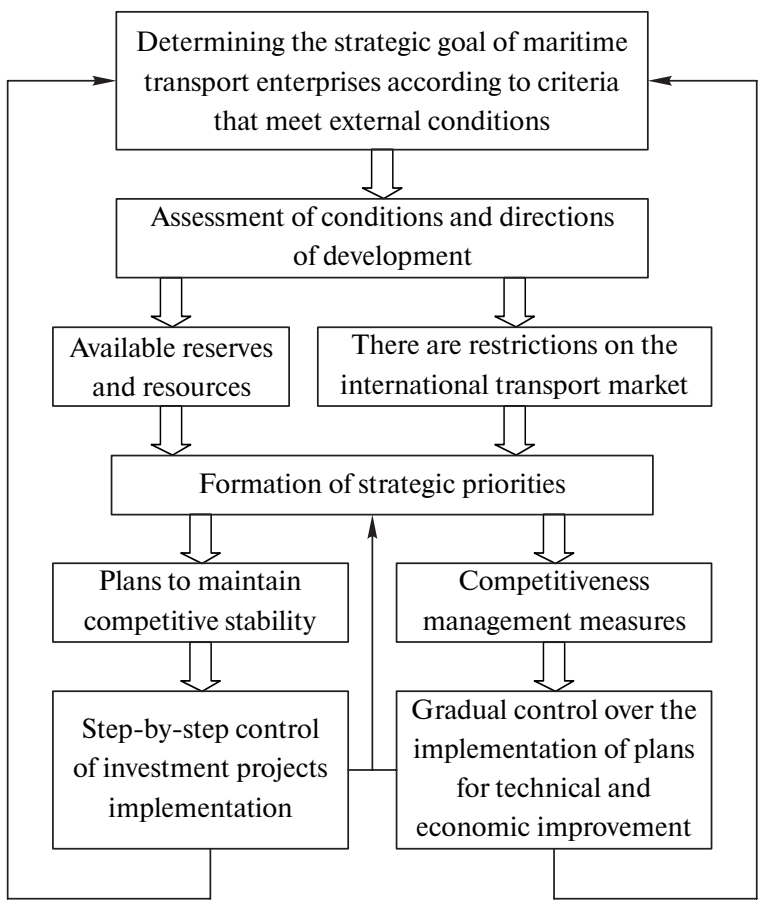

Fig. 1. Algorithm of criterial approach to sustainable and safe positioning of the fleet under restrictions on the international transport market 
Determining the strategic goal of maritime transport enterprises (Fig. 1) requires consideration of a complex set of differently directed factors in the presence of a significant number of constraints, which complicates the optimization of the use of their potential. Market conditions add to the growing difficulties for the operation of these enterprises on this issue. Therefore, the role of effective management of maritime transport enterprises in real time, in particular, in relation to logistics distribution systems is increasing.

Ukraine's geostrategic position provides additional opportunities for alternative routing of traffic flows. Consolidated simultaneous use of safer routes by transport companies and logistics operators would create preconditions for increasing the handling time of cargo in the ports located on these routes.

Therefore, the importance of coordinated actions of all participants in the transport services market is growing. The effectiveness of such coherence increases, firstly, in terms of forecasting the possibility of reorientation of routes associated with increased risks on a certain part of them, and secondly, in the presence of coordinated dynamic management of traffic flows. This increases the importance of tools and methods for modeling these changes associated with the level of risk.

Many of the technological processes associated with the operation of fleet transport units, in particular, to maintain reliability, performance and other parameters, are strictly regulated by external conditions and are limited by the relevant criteria stipulated by international conventions. Therefore, we propose that managers focus on the implementation of innovations that can change certain factors that affect the formation of current costs of the merchant fleet.

Since the limiting criterion for optimizing current costs is the issue of security [12], the main task of scientific work, whose results are presented in this article, was to develop a mathematical approach to minimize the risks of transportation of goods. This innovative technology, minimizing the risks in real time, allows reducing losses and forming the appropriate technical and economic level of maritime transport, which ensures the cost-effectiveness of cargo traffic. This approach increases the so-called "customer value" by consumers of services of shipping companies, which is primarily based on minimizing the time of transportation of goods and reducing the cost of transportation. This is one of the reasons for the growth of container transportation of goods and the use of multimodal transportation. But the use of the presented information technology is not limited to container transportation of goods. Risks of transportation are inherent in any cargoes transported by water transport. In this situation, preference will be given to those companies that can change routes and, even, for some time, directions, of transportation.

Rapid maneuver in case of increased risks on certain routes is quite possible, for example, for Ukrainian companies specializing in resource flows and focused on both foreign and domestic markets. In Ukraine, such a strategy is used by Nibulon Corporation. Therefore, such companies are also interested in technology to reduce the risks of real-time transportation routing.

As a result of using alternative routing of traffic flows to reduce risks by transport companies, logistics operators of safer routes should also take into account the totality of nontransport effect, the total productivity of transport process participants associated with the technical and economic level of the transport system. Rational use of an integrated multimodal transport system increases its efficiency and reliability by reducing the impact of risks and crises.

Decision-making should be based on the criteria of continuity of traffic flow handling.

Criteria for reducing the cost of goods delivery and continuity of trade services for the requirements of risk reduction stimulate the feasibility of interaction of transport process participants, determine the development of intermodal and multimodal transportation and modern logistics systems equipped with software to minimize these risks.
This allows creating conditions for sustainable and safe positioning of the Ukrainian fleet based on the prospects of optimizing the transport system of Ukraine to meet both regional economic needs and international transportation.

The results of the application of the block of methods of quantitative and qualitative comparison. We will analyze the volume of transit cargo (which to a greater extent meets the criteria of multimodality more than other types of transportation) through the ports of Ukraine (Fig. 2). The volume of transit traffic through all ports of Ukraine, except the port of Pivdennyi, tends to decrease significantly. As you know, the port of Pivdennyi, which also until 2016 had a tendency to reduce transit cargo (Fig. 2), has invested heavily in technological and technical upgrades. This is one of the reasons for the significant increase in transit traffic through this port. The general negative trend in relation to other ports is a generally negative picture for Ukraine, in terms of transit traffic (Fig. 2). The reason for this is the growing risks in their entirety for the Ukrainian fleet. A typical example of this is the volume of transit traffic through the port of Mariupol, which decreased, as shown in Fig. 2 [13], to zero. The reason for this is the risks associated with military actions and the delay of transport ships on one of the stages of the route to the port of Mariupol - in the Kerch Strait.

The results of the application of the block of methods of mathematical formalization. Thus, content analysis allows recording the presence of the impact of risks on routes, whose nodes are certain ports of Ukraine. These risks, as well as other transportation risks, are not constant over time. They can occur not only before the start of transportation but also after, when certain stages of cargo transportation have already been performed, and the next stages of the route are risky. Since the risks may be not only deterministic but also probabilistic, the probability of their occurrence in the subsequent stages of the route may increase or decrease during the previous stages. And to reduce the risks, it may be necessary to change the next stages of the route in real time. This requires the use of the latest information approaches.

The conclusion of the analysis of Fig. 2 is also that some routes to different ports of Ukraine in different periods may have differently directed effects of the relevant parameters.

The results of the method of mathematical formalization. Elements of approaches $[5,14]$ were used in the formation of the basic mathematical model. The scientific work [14] considers the optimization of cargo transportation in the logistics chain by the methods of the nearest neighbor and the Vogel approximation. In [5] a criterion approach to warehousing processes is proposed and its impact on the whole transport process is evaluated. However, in this study the mathematical apparatus presented in [16] was used as a basis with the appropriate modifications

Following the example of mathematical formalization given in [16], we consider the whole system of maritime transport of the Ukrainian fleet as an oriented graph, whose nodes are points/ports of loading/unloading of ships (Ukrainian and foreign), edges - transport routes connecting these points.

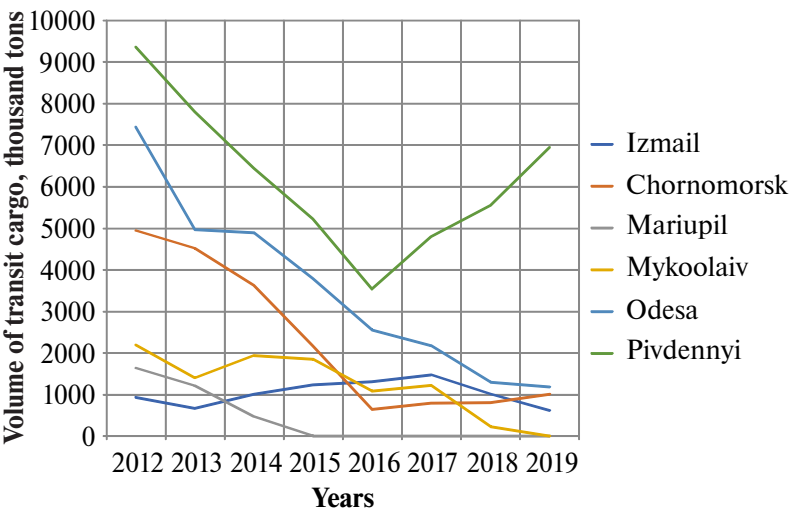

Fig. 2. Volumes of transit traffic through the ports of Ukraine 
Formally, this approach can be represented by a tensor equation of the following type [16]

$$
A Q=B,
$$

where are network connectivity tensors, respectively; the flow capacity of the oriented graph according to its individual edges; capacity of the edges in the presence of risks and the relevant criteria for positioning Ukraine in the market of transport services.

This approach allows building an algorithm to determine the probability of the required capacity of the branches of the integrated oriented graph for each specific transportation means and their totality. To do this, one needs to know the intervals of changes in risks and criteria for ensuring the sustainable operation of the fleet, which affect the choice of strategy and objectives for positioning Ukraine in the market of transport services. This allows choosing a route with an acceptable level of risk of transportation for each stage of each of the transport routes. Real-time information on the current intervals of changes in risks or criteria that meet the strategy and objectives of market positioning, makes it possible to estimate the probability of finding transportation means in each of the nodes, i. e. to present tensor $\boldsymbol{A}$ as a tensor of the probability of cargo flows in each node at the right time. This allows one, on the one hand, to assess in advance the availability of adequate capacity of the node, even in the event of significant threats on individual routes, on the other hand - to maintain the appropriate level of positioning of the fleet for threats.

If it is necessary to determine the change of parameters over time, we use the following dependencies, presented in [16] and modified in accordance with the task

$$
\begin{gathered}
\frac{d \theta}{d t}=\gamma(\vec{\theta}, \vec{\vartheta})+f(\vec{\theta}, \vec{\vartheta}) \times \vec{\mu} ; \\
\vec{Y}=y(\vec{\theta}, \vec{\vartheta}) ; \\
\vec{\vartheta}=N(\vec{u}, \vec{v}),
\end{gathered}
$$

under conditions $\mathrm{t} \in\left(t_{i} \ldots t_{i+1}\right), \vec{Y}(t) \in R^{k}, \vec{\theta}(t) \in R^{n}$, where $\vec{\theta}(t)$ is the state vector of the $n$-dimensional system at time $t$, where $n$ is the number of variables; $\vec{\mu}(t)$ is vector $k$ control actions in time $t$; ti, $t_{i+1}$ are respectively, the start time and end time of the $i^{\text {th }}$ stage of cargo transportation; $\vec{Y}(t) \in R^{k}$ is a vector that defines the boundaries of the intervals of the positioning criteria in time $t ; \vec{\vartheta}(t) \in R$ is vector of external influence on the system of maritime transport in time $t ; u \in R$, $\vec{v} \in R$ are vectors, respectively, of indeterminate and deterministic variable risks; $y, \gamma, f, M$ are vector functions of the defined variables.

The maritime traffic management algorithm is designed to harmonize two tasks: minimizing transportation time and transportation costs to meet the criteria

$$
\begin{gathered}
t_{i} \in[0, t] ; \\
C_{i} \leq C_{\max }, w_{j} \in W, i \in\left\{0, i_{\max }\right\},
\end{gathered}
$$

where $t_{i}$ is time of the beginning of the $i^{\text {th }}$ stage of transportations; $C_{i}$ is the cost of the $i^{\text {th }}$ stage of transportation.

The execution of the algorithm is implemented as follows. Divide the space $W$ into subspaces of probabilistic and deterministic variables. Then for the subspace of probabilistic variable risks

$$
T=\left\{(w, p)\langle F, \oplus\rangle \beta_{F}\right\},
$$

where $(\vec{w}, \vec{p})$ is part of the space $W$ for which each scalar of the matrix $\vec{w}$ is a probabilistic observation. In this case, each component of the vector $\vec{w}$ corresponds to the component of the probability vector $\vec{p}$, which can be described by a closed algebraic system of equations with objective function $F$, which has all the properties of the composition (ه); $\beta_{F}$ is a set of criteria for stable and safe positioning of the fleet.

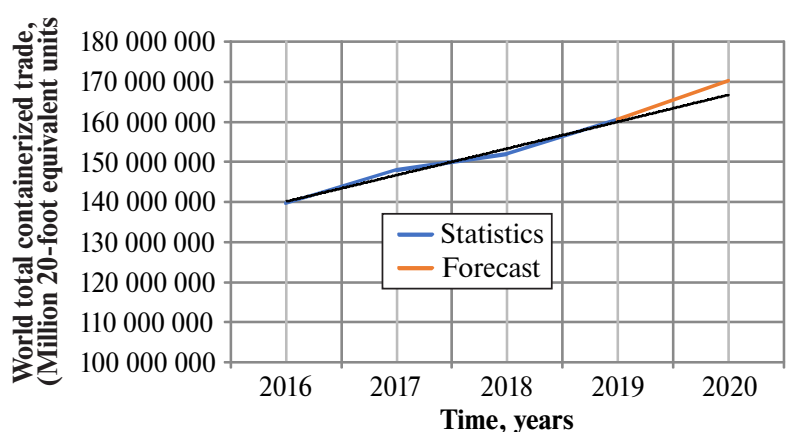

Fig. 3. Forecasting the volume of container traffic on the world market

For deterministic variable risks, a standard algorithm is used according to the corresponding functional dependencies.

Then the conditions of (2) can be represented as

$$
\begin{gathered}
t=\sum_{0}^{t} t_{i} \\
C=C_{1} \cdot C_{2} \times \ldots \times C_{i} \times \sum_{m}\left(+/-\delta_{k}\right) \rightarrow \min ,
\end{gathered}
$$

where $\delta_{k}$ is a parameter that takes into account integrated gains/losses, respectively, bonuses or penalties. The sign (*) in (9) means the operation of addition, provided the additivity of the cost function, or the operation of multiplication, provided its multiplicity. Multiplicity, in this case, means the corresponding property of the function $C\left(x_{1}, x_{2}\right)$, which is defined on the space of variable parameters $\theta$ so that for any variables belonging to the specified space $x_{1}, x_{2} \in \theta$, function $C\left(x_{1}, x_{2}\right)=$ $=C\left(x_{1}\right) C\left(x_{2}\right)$. Minimizing risks will help reduce the cost of $C$.

The presented mathematical model (1-4) allows, taking into account the risks, to predict the integrated volume of traffic through Ukrainian ports [19]. Since "the need for innovation to maintain the position of the merchant fleet is corrected by the need to expand intermodal transport technologies" [12] and that, even in terms of regional freight transport, positioning maritime transport systems in the market by external constraints requires adjustment of intermodal transport corridors [12], to confirm the practical significance of the study using statistical data on the volume of container traffic on the world market (Fig. 3) [17, 18] and to clarify the approaches [19] we predicted the volume of container traffic through the ports of Ukraine (Fig. 4) [13], which allows, according to [12] assessing the positioning of the fleet.

According to the authors' study, the level of risks listed in [19] is currently lower by $21-27 \%$, but the tariff policy of Black Sea ports of other countries will impose restrictions not taken into account in $[19,20]$ on the volume of transit and container traffic through Ukrainian ports. It is established that the projected increase in the volume of container traffic on the world market will not lead to an increase in the rate of traffic (the trend line is

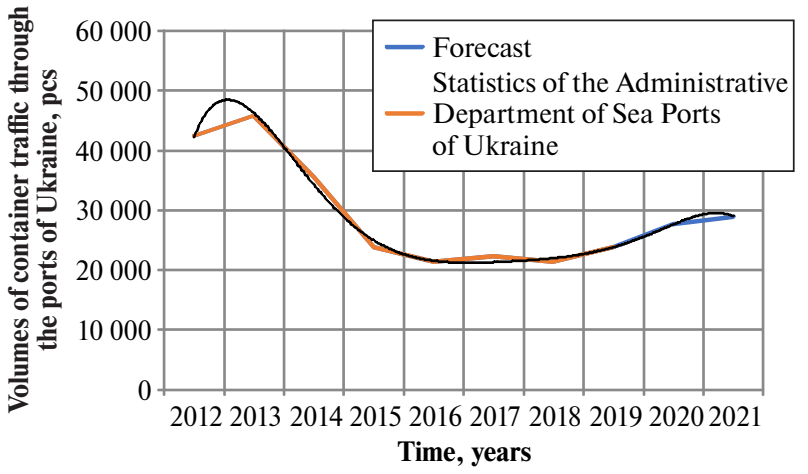

Fig. 4. Forecasting the volume of container traffic through the ports of Ukraine 
marked in black) in Ukrainian ports [21, 22]. The forecasting of the volume of container traffic through the ports of Ukraine and the comparative analysis with the forecast value of the volume of container traffic on the world market provided an opportunity to form a tool for assessing the positioning of the fleet.

Conclusions. The analysis indicates that the positioning of the fleet is adjusted to the need to expand multimodal technologies, which, by definition, are associated with the phased transportation of goods along their routes. An algorithm of criterion approach to sustainable and safe positioning of the fleet taking into account the limitations of the international transport market is proposed and a mathematical model of minimizing transportation risks is developed to strengthen the criteria for sustainable and safe positioning. Ukraine's geostrategic position provides additional opportunities for alternative routing of traffic flows, and the consolidated use of the proposed information technology by transport market participants will contribute to the positioning of the fleet, which will be enhanced not only by the ability to predict risky routes but also by coordinated dynamic traffic management.

The use of alternative routing of traffic flows to reduce risks should also take into account the non-transport effect associated with increased overall productivity of transport participants due to the growing technical and economic level of the national transport system. Rational use of an integrated multimodal transport system increases its efficiency and reliability.

Criteria for reducing the cost of transportation of goods and continuity of serving trade links while reducing risks form the prerequisites for the interaction of participants in the transport process with the use of software to minimize risks. This allows creating conditions for sustainable and safe positioning of the Ukrainian fleet based on the prospects of optimizing the transport system of Ukraine to meet both regional economic needs and international transportation.

For industrial enterprises, it is important to reduce the cost of their products to ensure fast and reliable delivery of finished products with lower overhead costs of supply of raw materials, components, equipment, and so on to the consumer. This supply, due to the reduction of loading and unloading operations, documentation, security of cargo, and others is provided by the growing market of container transportation.

The results of the study indicate that the projected increase in the volume of container traffic on the world market will not lead to a corresponding increase in the rate of container traffic in Ukrainian ports. Using the developed mathematical apparatus, forecasts of container traffic volumes through the ports of Ukraine were made, which in comparison with the corresponding forecasts for the world market of container traffic allows assessing the positioning of the fleet and indicates the efficiency and importance of investment re-equipment of transport infrastructure on the example of Pivdennyi port.

Comparative analysis of the volume of transit cargo through Ukrainian ports allowed establishing the impact of risks on the volume of transit cargo in certain areas, in particular, on the examples of the ports of Mariupol and Pivdennyi.

The application of the proposed algorithmic approach will help to increase the efficiency of management of transport enterprises and, as a consequence, increase the level of sustainable and safe positioning of the fleet.

\section{References.}

1. Yavorska, A. F. (2018). Criterial limitations of sustainable development of local maritime transport complexes. Economy and Society, 17, 182-186. https://doi.org/10.32782/25240072/2018-17-27.

2. Golubkova, I. (2018). Regularities of sustainable development of maritime cruise industry. Intellect XXI, 5, 42-46. Retrieved from http://www.intellect21.nuft.org.ua/journal/2018/2018 5/8.pdf.

3. Sienko, O. (2015). Dynamism of manifold in development of merchant shipping. The bulletin of transport and industry eco- nomics, 51, 108-113. https://doi.org/10.18664/338.47:338.45. v0i51.57478.

4. Makarenko, M., Ustynov, R., Sienko, H., \& Babachenko, M. (2019). Creating the Approach for the Evaluation Level of the Efficiency of the Organizational Culture of the Sea Port. In Proceedings of the $20197^{\text {th }}$ International Conference on Modeling, Development and Strategic Management of Economic System (MDSMES 2019), 249-254, https://doi.org/10.2991/ mdsmes-19.2019.47.

5. Nitsenko, V., Kotenko, S., Hanzhurenko, I., Mardani, A., Stashkevych, I., \& Karakai, M. (2020). Mathematical Modeling of Multimodal Transportation Risks, (pp. 439-447). In: Ghazali R., Nawi N., Deris M., Abawajy J. (Eds.). Recent Advances on Soft Computing and Data Mining. SCDM 2020. Advances in Intelligent Systems and Computing, 978. Springer, Cham. https://doi.org/10.1007/978-3-030-36056-6_41.

6. Koliadenko, S., Golubkova, I., Babachenko, M., Levinska, T., \& Burmaka, L. (2020). Development and use of it solutions in logistics. Financial and credit activity problems of theory and practice, 3(34), 230-236. https://doi.org/10.18371/fcaptp. v3i34.215518.

7. Sotnichenko, L., Solokha, D., \& Bessonova, S. (2018). Justification of business entities development based on innovate principles. Academy of Strategic Management Journal, 17(5). Retrieved from https://www.abacademies.org/articles/justification-of-business-entities-development-based-on-innovative-principles-7553.html.

8. Kosharskaya, L., Makhurenko, G., \& Postan, M. (2017). Application of the system approach to the development of the project of a safety management system for navigation in Ukraine. Eastern-European Journal of Enterprise technologies, 4/2(36), 29-36. https://doi.org/10.15587/2312-8372.2017.109094.

9. Bubnova, G. V., Efimova, O. V., Karapetyants, I. V., \& Kurenkov, P. V. (2018). Digitalization of intellectualization of logistics of intermodal and multimodal transport. MATEC Web of Conferences, 236(149), 02013. https://doi.org/10.1051/ matecconf $/ 201823602013$.

10. Morozova, K. (2020). Transport and logistics prospects of sea and river ports of the South of Ukraine. Retrieved from https://eba.com.ua/transportno-logistychni-perspektyvymorskyh-ta-richkovyh-portiv-pivdnya-ukrayiny/.

11. Kolehaiev, I. M. (2017). Principles of competitive development of specialized shipping in the global maritime industry. monograph. Odesa: NU "OMU”.

12. Pavlova, O. (2018). Politically-Technological Potential of Cultural Practices in Ukrainian Perspective. Ukrainian Policymaker, 2, 20-26. https://doi.org/10.29202/up/2/3.

13. Ukrainian Sea Ports Authority (2020). Performance indicators. Retrieved from http://www.uspa.gov.ua/pokazniki-roboti. 14. Pečený, L., Meškoa, P., Kampfb, R., \& Gašparíka, J. (2020). Optimization in Transport and Logistic Processes. Transportation Research Procedia, 44, 15-22, https://doi. org/10.1016/j.trpro.2020.02.003.

15. Nguyen, N. T. (2020). Marine Culture of Northeast Vietnam: Approaching from the Theory of Culture Ecology. Future Human Image, 13, 66-75. https://doi.org/10.29202/fhi/13/7.

16. Stopka, O., \& Kampf, R. (2016). Determining the most suitable layout of space for the loading units handling in the maritime port. Transport, 33, 280-290. https://doi.org/10.384 6/16484142.2016.1174882.

17. Kumar, S. (2020). 2020 World Maritime Review. Retrieved from https://www.researchgate.net/publication/341555516 2020 World_Maritime_Review/ link/5ec72180458515626cbf30a3/download.

18. UNCTAD (2019). Review of Maritime Transport. Report by the UNCTAD secretariat. United Nations New York and Geneva. Retrieved from https://unctad.org/system/files/official-document/rmt2019 en.pdf.

19. Kotenko, S., Nitsenko, V., Hanzhurenko, I., \& Havrysh, V. (2020). The Mathematical Modeling Stages of Combining the Carriage of Goods for Indefinite, Fuzzy and Stochastic Pa- 
rameters. International Journal of integrated engineering, 12, 7(20), 173-180. https://doi.org/10.30880/ijie.2020.12.07.019. 20. Piliaiev, I. (2019). The Value Dichotomy Curse of Ukraine's Modernization: to Break, or not to Be. Ukrainian Policymaker, 5, 68-76. https://doi.org/10.29202/up/5/8.

21. Mikhno, I., Koval, V., Shvets, G., Garmatiuk, O., \& Tamošiūnienè, R. (2021). Discussion: Green Economy in Sustainable Development and Improvement of Resource Efficiency. Central European Business Review, 10(XX), 1-15. https://doi.org/10.18267/j.cebr.252.

22. Nitsenko, V., Nyenno, I., Kryukova, I., Kalyna, T., \& Plotnikova, M. (2017). Business model for a sea commercial port as a way to reach sustainable development goals. Journal of Security and Sustainability Issues, 7(1), 155-166. https://doi. org/10.9770/jssi.2017.7.1(13).

\section{Критерії менеджменту сталого й безпечного функціонування флоту в умовах глобалізації}

\section{I. А. Голубкова ${ }^{1}$, О. В. Сєнько ${ }^{1}$, Н. С. Лисенко ${ }^{2}$, T. I. Фрасинюк ${ }^{1}$, I. М. Пархоменко ${ }^{1}$}

1 - Національний університет «Одеська морська академія», м. Одеса, Україна, e-mail: prof.irinagolubkova@gmail.com

2 - ПП «Вавілонт», м. Одеса, Україна

Мета. Розробити модель мінімізації ризиків перевезення для посилення критеріальних передумов сталого й безпечного позиціонування флоту.

Методика. Наукове дослідження, результати якого наведені у представленій статті, виконано із зістосуванням як загальних, так і спеціальних методів пізнання. Були застосовані методи кількісного та якісного порівняння, контент-аналізу, наукового абстрагування й систематизації та метод математичної формалізації.

Результати. Запропоновано алгоритм критеріального підходу до сталого й безпечного позиціонування флоту за наявності обмежень міжнародного транспортного ринку. Розроблена математична модель мінімізації ризиків перевезення, що дозолить знизити поточні витрати діяльності торгового флоту та, відповідно, сприятиме його сталому й безпечному позиціонуванню. Оскільки для промислових підприємств важливим є зменшення часу й собівартості доставки сировини, комплектуючих, зменшення транспортних витрат на доставку своєї продукції споживачеві, у представленій роботі надано прогнозування обсягів контейнерних перевезень через порти України та проведено порівняльний аналіз із прогнозним трендом контейнерних перевезень на світовому ринку. Це надало можливість сформувати інструмент для визначення відповідного позиціонування флоту.

Наукова новизна. У ході дослідження розроблені алгоритм критеріального підходу до сталого й безпечного позиціонування флоту за наявності обмежень міжнародного транспортного ринку та математична модель мінімізації ризиків перевезення. Це дозволяє перейти до формування цілісної мультимодальної транспортної системи та злагоджених дій усіх учасників ринку транспортних послуг. Ефективність і надійність системи буде посилюватися можливістю прогнозуванням переорієнтації маршрутів, пов'язаних із посиленням ризиків, і динамічного керування транспортними потоками.

Практична значимість. Результати дослідження можуть бути використані для створення інтегрованих автоматизованих інформаційних систем динамічного керування перевезеннями з використанням альтернативної маршрутизації транспортних потоків задля мінімізації ризиків. Наведені результати прогнозного дослідження контейнерних перевезень через українські морські портів можуть бути використані для практичних чи наукових цілей.
Ключові слова: інноваційні технології, морські перевезення, критерії стійкого функціонування, ефективність, позиціонування, менеджмент

\section{Критерии менеджмента устойчивого и безопасного функционирования флота в условиях глобализации}

\section{И. А. Голубкова ${ }^{1}$, Е. В. Сенько ${ }^{1}$ Н. С. Лысенко ${ }^{2}$, Т. И. Фрасинюк ${ }^{1}$, И. Н. Пархоменко ${ }^{1}$}

1 - Национальный университет «Одесская морская академия», г. Одесса, Украина, e-mail: prof.irinagolubkova@ gmail.com

2 - ЧП «Вавилонт», г. Одесса, Украина

Цель. Разработать модель минимизации рисков перевозки для усиления критериальных предпосылок устойчивого и безопасного позиционирования флота.

Методика. Научное исследование, результаты которого приведены в представленной статье, выполнены с применением как общих, так и специальных методов познания. Были применены методы количественного и качественного сравнения, контент-анализа, научного абстрагирования и систематизации и метод математической формализации.

Результаты. Предложен алгоритм критериального подхода к устойчивому и безопасному позиционированию флота при наличии ограничений международного транспортного рынка Разработана математическая модель минимизации рисков перевозки, что позволит снизить текущие расходы деятельности торгового флота и, соответственно, способствовать его устойчивому и безопасному позиционированию. Поскольку для промышленных предприятий важным является уменьшение времени и себестоимости доставки сырья, комплектующих, уменьшение транспортных расходов на доставку продукции потребителю, в представленной работе дано прогнозирование объемов контейнерных перевозок через порты Украины и проведен сравнительный анализ с прогнозным трендом контейнерных перевозок на мировом рынке. Это дало возможность сформировать инструмент для определения соответствующего позиционирования флота.

Научная новизна. В ходе исследования разработаны алгоритм критериального подхода к устойчивому и безопасному позиционированию флота при наличии ограничений международного транспортного рынка и математическая модель минимизации рисков перевозки. Это позволяет перейти к формированию целостной мультимодальной транспортной системы и слаженных действий всех участников рынка транспортных услуг. Эффективность и надежность системы будет усиливаться возможностью прогнозирования переориентации маршрутов, связанных с усилением рисков, и динамического управления транспортными потоками.

Практическая значимость. Результаты исследования могут быть использованы для создания интегрированных автоматизированных информационных систем динамического управления перевозками с использованием альтернативной маршрутизации транспортных потоков для минимизации рисков. Приведенные результаты прогнозного исследования контейнерных перевозок через украинские морские порты могут быть использованы для практических или научных целей.

Ключевые слова: инновационные технологии, морские перевозки, критерии устойчивого функиионирования, э фективность, позиционирование, менеджмент

Recommended for publication by L. L. Sotnychenko, Doctor of Economic Sciences. The manuscript was submitted 18.11.20. 